\title{
ANALYSIS OF DENOTATIVE AND CONNOTATIVE MEANINGS ON SONG LYRICS BY IWAN FALS
}

\author{
Yogi Purnama*), \\ Universitas Indraprasta PGRI \\ Royan Nur Fahmi, \\ Badan Pengembangan dan Pembinaan Bahasa, Kementerian Pendidikan dan Kebudayaan \\ *) Correspondences author: Jl. Nangka No. 58C Tanjung Barat, Jagakarsa, Jakarta Selatan, Indonesia \\ e-mail: yogi.purnama@unindra.ac.id \\ royan.nurfahmi@kemdikbud.go.id
}

\begin{abstract}
This study aims to describe the meaning of denotation, connotations, in the lyrics of Iwan Fals songs. The method used in this research is to use a qualitative descriptive approach to reveal the meaning of denomination and connotation. Data collection techniques are carried out using the analysis of sentence expressions. This study resulted in the conclusion that the use of denotative meaning by $68.75 \%$, the use of positive connotative meaning by $21.09 \%$, the use of negative connotative meaning by $11.32 \%$.
\end{abstract}

Key Words: denotation, connotations, in the lyrics of Iwan Fals songs Fals.

Article History: Received: 09/10/2020; Revised: 15/10/2020; Accepted: 25/11/2020; Published: 31/12/2020

How to Cite (MLA $7^{\text {th }}$ ): Purnama, Yogi and Royan Nur Fahmi “Analisis Makna Denotatif dan Konotatif pada Lirik Lagu Karya Iwan Fals.” Hortatori Jurnal Pendidikan Bahasa dan Sastra Indonesia vol. 04 no. 02 (2020): 78-86. Print/Online. Copyrights Holder: Yogi Purnama, Royan Nur Fahmi. First Publication: Hortatori Jurnal Pendidikan Bahasa dan Sastra Indonesia (2020).

This work is licensed under a Creative Commons Attribution-ShareAlike 4.0 International License.

\section{Pendahuluan}

Musik merupakan salah satu media komunikasi yang ditandai oleh adanya komunikasi searah, dalam komunikasi searah si pengirim tetap sebagai pengirim dan si penerima tetap sebagai penerima, tidak menutup kemungkinan dalam musik juga terjadi umpan balik si pendengar terhadap si pengirim. "Musik sangatlah berpengaruh dalam penyampian pesan" (Halimah) pesan yang disampaikan kepada masyarakat tentang ekspresi diri, hal ini dapat dipengaruhi oleh kondisi disekitar, musik sangatlah melekat pada diri manusia. Pada saat kita mendengarkan musik lirik menjadi bagian yang didengar, dihafalkan (Setiadi) teks kalimat pada lirik lagu sering menggunakan pilihan kata yang mengundang rasa keingintahuan pendengar sehingga bahasa yang digunakan dalam lirik lagu seringkali mengabaikan aturan gramatikal, dan pilihan kata yang digunakan sering bermakna khusus atau memiliki makna lain, dalam linguistik disebut dengan makna denotatif dan konotatif. Manusia dapat berfikir dan mengungkapkan pengalaman batinnya, seperti dalam penciptaan seni sastra, karna kemampuannya

Makna denotatif pada dasarnya sama dengan makna referensial. "Makna denotatif adalah makna jelas (Sabriah) Jadi, makna denotatif ini menyangkut informasi-informasi faktual objektif atau sebenarnya, denotatif juga dikatakan tidak mengandung perasaan tambahan (Wahyuningsih). Lalu karena itu makna denotasi sering disebut makna sebenarnya. Sebuah kata disebut mempunyai makna konotatif apabila makna itu mempunyai nilai rasa, baik positif maupun negatif, jika tidak memiliki nilai rasa maka dikatakan tidak memiliki konotasi. Tetapi dapat juga disebut berkonotasi netral. Makna konotatif adalah 
tidak disampaikan dengan terus terang (Sabriah), bisa dikatakan makna tambahan, makna yang bukan makna sebenarnya atau berasosiasi dengan pengertian lain, konotatif adalah kata yang mengandung nilai emosional (Wahyuningsih). Untuk nilai rasa sendiri terjadi perubahan makna (Afrinda) perubahan yang terjadi dapatlah bersifat halus, kasar, indah, dan kgonkrit atau tegas. Seperti yang dinyatakan oleh Pradopo bahwa nilai sastra ditentukan oleh gaya bahasanya. (Pradopo)

Sosok Iwan Fals sendiri memang fenomenal dan saat ini karyanya masih banyak digandrungi anak muda khususnya milenial, dalam karyanya tidak hanya bertemakan cinta tetapi ada pula bertemakan kritik sosial yang dianggap masih sangat relevan dengan kehidupan saat ini, misalnya dalam menyuarakan ketidakadilan, kemiskinan, anti kemapanan, dan lain-lain. Aspek lingkungan menjadi potensi intensi emosional bahkan estetis dalam merespon musik (Jatmika)

Mulai dari album pertamanya sampai sekarang. Ia menjadi sosok yang banyak dibicarakan, ada yang berbicara tentang lirik lagunya, cara bernyanyinya, gaya hidupnya. Kehadiran Iwan menjadi semakin nyata seiring dengan munculnya persoalan-persoalan yang membakar emosi masyarakat, dengan penampilan dan kekuatan pada tiap liriknya, ia bagaikan seorang pendongeng yang mengagumkan lewat alunan lagunya. dan dari berbagai persoalan itulah ia mengemas ide lagunya. Kehidupan baginya adalah kitab yang terbuka. Ia membaca, mencatat bagian-bagian yang penting, lalu mengolah dengan nuraninya. Ia selalu berpihak pada orang-orang yang tertindas oleh nasib buruk. Oleh sebab itulah terkadang ia menjadi marah terhadap sistem sosial yang mulai kehilangan kepekaan pada persoalan orang-orang kecil. Dalam kemarahannya itu, ia bisa berteriak kepada siapa saja, kepada manusia dan nasib, kepada bumi dan langit, dan bertanya pada sang pencipta. Ketika menyanyikan lagu dari sepotong baitnya "hatiku rasa bukan takdir tuhan karena aku yakin itu tak mungkin korbankan ratusan jiwa demi peringatan manusia", yang berdenotasi ia bahkan terdengar seperti orang yang meragukan takdir Tuhan yang bercerita tentang bencana terbakarnya kapal tampomas II di Kep. Masalembo, 27 januari 1981.

Iwan telah menjadi superstar, baik di panggung musik maupun di panggung lebih luas dari pada itu. Ia memang tidak pernah mengkritik secara langsung tapi ditunjukan bahwa di sekitar kita banyak sekali masalah, tapi ia selalu menyapa orang-orang yang nasibnya selalu ditendang oleh arus besar, contohnya menyapa kaum lemah seperti pada lagu "Terminal" yang dinyayikan bersama Franky Sahilatuha "Kudatangi lewat laguku datangi kamu langitku masih biru”. Yang bermakna konotasi ia akan datang meski tak bisa bertemu muka tapi lagunya yang pasti bertemu dengan jiwa mu. Iwan juga menulis tentang keserakahan manusia dalam lagu yang berkonotasai "Kisah usang tikus-tikus kantor " kata Tikus adalah hewan jorok, jahat, suka mencuri, dan merugikan manusia, dalam lirik tersebut timbul kesan bahwa tikus-tikus kantor adalah seorang koruptor yang banyak merugikan manusia. Orang boleh meremehkan lagu-lagunya, tapi "jiwa" dari lagunya akan menyentuh siapapun yang mengaku berbudaya. Ayah dari tiga anak ini sudah menjadi seorang legenda.

Ada beberapa penelitian terkait analisis lirik lagu, seperti penelitian Laila Adha yang meneliti mengenai lirik lagu dari grup band Padi (Adha). Selain itu, ada juga penelitian mengenai analisis makna denotatif dan konotatif yang dilakukan oleh (Agustina). Namun sejauh ini belum ada penelitian mengenai analisis denotatif dan konotatif pada lirik lagu.

Teks pada lirik lagu mengandung makna denotatif dan konotatif yang diperlihatkan melalui pilihan kata yang digunakan untuk menggambarkan kereatifitas agar sesuai dengan citraan yang ingin ditampilkan. Berdasarkan latar belakang inilah maka akan dilakukan penelitian tentang analisis makna denotatif dan konotatif pada lirik lagu karya Iwan Fals.

\section{Metode}

Metode penelitian yang digunakan adalah metode pendekatan kualitatif dengan teknik deskriptif, Penelitian dengan menggunakan metode atau pendekatan. Penelitian ini berbentuk triangulasi data, dengan metode ini penulis akan mengumpulkan sampel sebanyak 15 judul lagu dan data yang akan diteliti adalah analisis makna denotatif dan konotatif baik negatif maupun positif dan objeknya adalah lirik lagu karya Iwan Fals baik terhadap kritik sosial maupun cinta. 


\section{Hasil dan Diskusi}

Berdasarkan analisis dari lirik-lirik lagu yang diambil dari tahun 1981 sampai dengan 2005 yang dinyanyikan Iwan Fals, peneliti dapat mendeskripsikan informasi tentang makna denotatif dan konotatif pada lirik lagu karya Iwan Fals. Data yang berupa lirik-lirik lagu diperoleh dari kaset pita dan teks-teks lagu sebanyak 15 yang menjadi sampel penelitian. Hasil temuan dari keseluruhan dapat dilihat pada tabel berikut:

\begin{tabular}{|c|c|c|c|c|c|}
\hline \multirow[t]{3}{*}{ No } & \multirow[t]{3}{*}{ Judul Lagu } & \multirow[t]{3}{*}{ Lirik lagu } & \multicolumn{3}{|c|}{ Jenis makna } \\
\hline & & & \multirow[t]{2}{*}{ Denotatif } & \multicolumn{2}{|c|}{ Konotattif } \\
\hline & & & & Positif & Negatif \\
\hline \multirow{12}{*}{1} & \multirow{12}{*}{$\begin{array}{l}22 \text { Januari } \\
\text { (Cinta) }\end{array}$} & 22 Januari kita berjanji & $\sqrt{ }$ & & \\
\hline & & coba saling mengerti apa di dalam hati & $\sqrt{ }$ & & \\
\hline & & 22 Januari ku tidak sendiri & $\sqrt{ }$ & & \\
\hline & & Aku berteman iblis yang baik hati & & & \\
\hline & & Jalan berdampingan tak pernah ada tujuan & $\sqrt{ }$ & & \\
\hline & & $\begin{array}{l}\text { Membelah malam mendung yang s'lalu } \\
\text { datang }\end{array}$ & & $\sqrt{ }$ & \\
\hline & & Ku dekap erat kupandang senyummu & $\sqrt{ }$ & & \\
\hline & & Dengan sorot mata yang keduanya buta & $\sqrt{ }$ & & \\
\hline & & $\begin{array}{l}\text { Lalu kubisikan sebaris kata-kata putus asa } \\
\text { sebentar lagi hujan }\end{array}$ & $\sqrt{ }$ & & \\
\hline & & $\begin{array}{l}\text { Dua buku teori kau pinjamkan aku tebal } \\
\text { tak berdebu kan ku baca s'lalu }\end{array}$ & $\sqrt{ }$ & & \\
\hline & & Empat lembar fotomu dalam lemari kayu & $\sqrt{ }$ & & \\
\hline & & Ku pandang dan ku jaga sampai kita jemu & $\sqrt{ }$ & & \\
\hline \multirow{18}{*}{2} & \multirow{18}{*}{$\begin{array}{l}\text { Aku Sayang Kamu } \\
\text { (Cinta) }\end{array}$} & Susah-susah mudah kau ku dekati & $\sqrt{ }$ & & \\
\hline & & Kucari engkau lari ku diam kau hampiri & $\sqrt{ }$ & & \\
\hline & & Jinak burung dara justru itu ku suka & & $\sqrt{ }$ & \\
\hline & & Bila engkau tertawa hilang semua duka & $\sqrt{ }$ & & \\
\hline & & $\begin{array}{l}\text { Gampang naik darah omong tak mau } \\
\text { kalah }\end{array}$ & $\sqrt{ }$ & & \\
\hline & & Kalau datang senang nona cukup ramah & $\sqrt{ }$ & & \\
\hline & & Bila engkau bicara persetan logika & & & \\
\hline & & Sedikit keras kepala ah dasar betina & & & \\
\hline & & Ku suka kamu sungguh suka kamu & $\sqrt{ }$ & & \\
\hline & & Ku perlu kamu sungguh perlu kamu & $\sqrt{ }$ & & \\
\hline & & Engkau aku sayang sampai dalam tulang & & $\sqrt{ }$ & \\
\hline & & $\begin{array}{l}\begin{array}{l}\text { Banyak orang bilang aku mabuk } \\
\text { kepayang }\end{array}\end{array}$ & & $\sqrt{ }$ & \\
\hline & & Aku cinta kamu bukan cinta uangmu & $\sqrt{ }$ & & \\
\hline & & Aku puja selalu setiap ada waktu & $\sqrt{ }$ & & \\
\hline & & Langsat kulit cina warna kulit nona & $\sqrt{ }$ & & \\
\hline & & Bibir merah muda lesung pipit pun ada & $\sqrt{ }$ & & \\
\hline & & Wajah cukup lumayan dapat point enam & $\sqrt{ }$ & & \\
\hline & & Kalau nona berjalan rembulan pun padam & & $\sqrt{ }$ & \\
\hline \multirow{19}{*}{3} & \multirow{17}{*}{$\begin{array}{l}\text { Belum Ada Judul } \\
\text { (Kritik Sosial) }\end{array}$} & Pernah kita sama-sama susah & $\sqrt{ }$ & & \\
\hline & & Terperangkap di dingin malam & & $\sqrt{ }$ & \\
\hline & & Terjerumus dalam lubang jalanan & & & \\
\hline & & Digilas kaki sang waktu yang sombong & & $\sqrt{ }$ & \\
\hline & & Terjerat mimpi yang indah lelah & & & \\
\hline & & Pernah kita sama-sama rasakan & $\sqrt{ }$ & & \\
\hline & & Panasnya mentari hanguskan hati & & $\sqrt{ }$ & \\
\hline & & Sampai saat kita nyaris tak percaya & $\sqrt{ }$ & & \\
\hline & & Bahwa roda nasib memang berputar & & $\sqrt{ }$ & \\
\hline & & Sahabat masih ingat kah kau & $\sqrt{ }$ & & \\
\hline & & Sementara hari terus berganti & $\sqrt{ }$ & & \\
\hline & & $\begin{array}{l}\text { Engkau pergi dengan dendam membara } \\
\text { dihati }\end{array}$ & & $\sqrt{ }$ & \\
\hline & & Cukup lama aku jalan sendiri & $\sqrt{ }$ & & \\
\hline & & Tanpa teman yang sanggup mengerti & $\sqrt{ }$ & & \\
\hline & & Hingga saat kita jumpa hari ini & $\sqrt{ }$ & & \\
\hline & & Tajamnya mata mu tikam jiwa ku & & $\sqrt{ }$ & \\
\hline & & Kau tampar bangkitkan aku sobat & $\sqrt{ }$ & & \\
\hline & & Kalau cinta sudah dibuang & & & \\
\hline & & Jangan harap keadilan akan datang & $\sqrt{ }$ & & \\
\hline
\end{tabular}




\begin{tabular}{|c|c|c|c|c|c|}
\hline \multirow{15}{*}{4} & \multirow{15}{*}{$\begin{array}{c}\text { Bongkar } \\
\text { (Kritik Sosial) }\end{array}$} & $\begin{array}{l}\text { Kesedihan hanya tontonan bagi nereka } \\
\text { yang diperbudak jabatan }\end{array}$ & & & \\
\hline & & Oh..o..ya..oo..ya......Bongkar & $\sqrt{ }$ & & \\
\hline & & $\begin{array}{l}\text { Sabar-sabar dan tunggu itu jawaban yang } \\
\text { kami terima }\end{array}$ & $\sqrt{ }$ & & \\
\hline & & Ternyata kita harus kejalan & $\sqrt{ }$ & & \\
\hline & & $\begin{array}{lll}\begin{array}{l}\text { Robohkan setan } \\
\text { mengangkang }\end{array} & \text { yang berdiri } \\
\end{array}$ & & & \\
\hline & & Oh..o..ya..oo..ya.....Bongkar & $\sqrt{ }$ & & \\
\hline & & Pinindasan serta kesewenang-wenangan & $\sqrt{ }$ & & \\
\hline & & $\begin{array}{l}\text { Banyak lagi teramat banyak untuk } \\
\text { disebutkan }\end{array}$ & $\sqrt{ }$ & & \\
\hline & & Hoi hentikan-hentikan jangan diteruskan & $\sqrt{ }$ & & \\
\hline & & $\begin{array}{l}\text { Kami muak dengan ketidak pastian dan } \\
\text { keserakahan }\end{array}$ & $\sqrt{ }$ & & \\
\hline & & $\begin{array}{l}\text { Dijalanan kami sandarkan cita-cita sebab } \\
\text { dirumah }\end{array}$ & & $\sqrt{ }$ & \\
\hline & & Sudah tidak ada lagi yang bias dipercaya & $\sqrt{ }$ & & \\
\hline & & Orang tua pandanglah kami & $\sqrt{ }$ & & \\
\hline & & Sebagai manusia kami bertanya & $\sqrt{ }$ & & \\
\hline & & 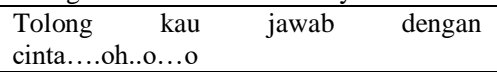 & & $\sqrt{ }$ & \\
\hline \multirow{16}{*}{5} & \multirow{16}{*}{$\begin{array}{l}\text { Buku Ini Aku Pinjam } \\
\text { (Cinta) }\end{array}$} & Biar tau biar rasa cinta ini milik kita & $\sqrt{ }$ & & \\
\hline & & $\begin{array}{l}\text { Di kantin depan kelas ku di sana kenal } \\
\text { dirimu }\end{array}$ & $\sqrt{ }$ & & \\
\hline & & $\begin{array}{l}\text { Yang kini tersimpan dihati jalani kisah } \\
\text { sembunyi }\end{array}$ & & $\sqrt{ }$ & \\
\hline & & $\begin{array}{l}\text { Di halte itu ku tunggu senyum manismu } \\
\text { kekasih }\end{array}$ & $\sqrt{ }$ & & \\
\hline & & $\begin{array}{l}\text { Usai dentang bel sekolah kita nikmati } \\
\text { yang ada }\end{array}$ & $\sqrt{ }$ & & \\
\hline & & $\begin{array}{l}\text { Seperti hari yang lain kau senyum tersipu } \\
\text { malu }\end{array}$ & $\sqrt{ }$ & & \\
\hline & & Ketika ku sapa engkau genggam lah jari & $\sqrt{ }$ & & \\
\hline & & Genggam lah hati ini & & $\sqrt{ }$ & \\
\hline & & $\begin{array}{l}\text { Memang usia kita muda namun cinta soal } \\
\text { hati }\end{array}$ & $\sqrt{ }$ & & \\
\hline & & Biar mereka bicara telinga kita terkunci & & $\sqrt{ }$ & \\
\hline & & $\begin{array}{l}\text { Biar tau biar rasa maka tersenyumlah } \\
\text { kasih }\end{array}$ & $\sqrt{ }$ & & \\
\hline & & Tetap langkah jangan hentikan & $\sqrt{ }$ & & \\
\hline & & Cinta ini milik kita & $\sqrt{ }$ & & \\
\hline & & $\begin{array}{l}\text { Buku ini aku pinjam kan ku tulis sajak } \\
\text { indah }\end{array}$ & $\sqrt{ }$ & & \\
\hline & & Hannya untukmu seorang & $\sqrt{ }$ & & \\
\hline & & Tentang mimpi-mimpi malam & & $\sqrt{ }$ & \\
\hline \multirow{19}{*}{6} & \multirow{12}{*}{$\begin{array}{l}\text { Do'a Pengobral Dosa } \\
\text { (Kritik Sosial) }\end{array}$} & Di sudut dekat gerbong yang tak terpakai & $\sqrt{ }$ & & \\
\hline & & $\begin{array}{l}\text { Perempuan bermek-up tebal dengan } \\
\text { rokok ditangan }\end{array}$ & & & \\
\hline & & Menunggu tamu yang datang & $\sqrt{ }$ & & \\
\hline & & $\begin{array}{l}\text { Terpisah dari ramai berteman nyamuk } \\
\text { nakal }\end{array}$ & & & \\
\hline & & Dari segumpal harapan & & $\sqrt{ }$ & \\
\hline & & Kapankah datang tuan berkantong tebal & & $\sqrt{ }$ & \\
\hline & & $\begin{array}{l}\text { Habis berbatang-batang tuan belum } \\
\text { datang }\end{array}$ & $\sqrt{ }$ & & \\
\hline & & Dalam hati resah menjerit bimbang & & $\sqrt{ }$ & \\
\hline & & $\begin{array}{l}\text { Apakah esok hari Anak-anak ku dapat } \\
\text { makan }\end{array}$ & $\sqrt{ }$ & & \\
\hline & & Oh tuhan beri setetes rezeki & $\sqrt{ }$ & & \\
\hline & & Dalam hati yang bimbang berdoa & & $\sqrt{ }$ & \\
\hline & & $\begin{array}{l}\text { Beri terang jalan anak hamba kabulkan } \\
\text { lah tuhan }\end{array}$ & & $\sqrt{ }$ & \\
\hline & & Entah mengapa aku tak berdaya & $\sqrt{ }$ & & \\
\hline & & $\begin{array}{l}\text { Waktu kau bisikan jangan aku kau } \\
\text { tinggalkan }\end{array}$ & & & \\
\hline & & Tak tahu dimana ada getar terasa & $\sqrt{ }$ & & \\
\hline & & $\begin{array}{l}\text { Waktu kau katakana ku butuh dekat } \\
\text { dengan mu }\end{array}$ & $\sqrt{ }$ & & \\
\hline & & Seperti biasa aku diam tak bicara & $\sqrt{ }$ & & \\
\hline & & $\begin{array}{l}\text { Hanya mampu pandangi bibir tipismu } \\
\text { yang menarik }\end{array}$ & $\sqrt{ }$ & & \\
\hline & & Seperti biasa aku tak sanggup berjanji & $\sqrt{ }$ & & \\
\hline
\end{tabular}




\begin{tabular}{|c|c|c|c|c|c|}
\hline \multirow{9}{*}{7} & \multirow{9}{*}{$\begin{array}{l}\text { Entah } \\
\text { (Cinta) }\end{array}$} & $\begin{array}{l}\text { Hanya mampu katakana aku cinta kau } \\
\text { saat ini }\end{array}$ & $\sqrt{ }$ & & \\
\hline & & Entah esok hari..Entah lusa nanti..Entah & $\sqrt{ }$ & & \\
\hline & & Sungguh mati betinaku & & & \\
\hline & & Aku tak mampu beri sayang yang cantik & & $\sqrt{ }$ & \\
\hline & & Seperti kisah cinta di dalam komik & $\sqrt{ }$ & & \\
\hline & & Sungguh mati betinaku & & & \\
\hline & & $\begin{array}{l}\text { Buang saja angan-angan itu Lalu cepat } \\
\text { peluk aku }\end{array}$ & & & \\
\hline & & Lanjutkan saja langkah kita & $\sqrt{ }$ & & \\
\hline & & Rasalah....rasalah apa yang terasa & $\sqrt{ }$ & & \\
\hline \multirow{14}{*}{8} & \multirow{14}{*}{$\begin{array}{c}\text { Lonteku } \\
\text { (Kritik Sosial) }\end{array}$} & Hembusan angin malam waktu itu & $\sqrt{ }$ & & \\
\hline & & Bawa lariku dalam dekapan mu & $\sqrt{ }$ & & \\
\hline & & Kau usap luka disekujur tubuh ini & $\sqrt{ }$ & & \\
\hline & & Sembunyilah-sembunyi ucapmu & $\sqrt{ }$ & & \\
\hline & & Nampak jelas rasa takut diwajah mu & $\sqrt{ }$ & & \\
\hline & & Saat petugas datang mencari ku & $\sqrt{ }$ & & \\
\hline & & Lonteku terima kasih & & & \\
\hline & & Atas pertolongan mu di malam itu & $\sqrt{ }$ & & \\
\hline & & Lonteku dekat padaku & & & \\
\hline & & Mari kita lanjutkan cerita hari esok & $\sqrt{ }$ & & \\
\hline & & Walau kita berjalan dalam dunia hitam & & & \\
\hline & & Benih cinta tak pandang siapa & & $\sqrt{ }$ & \\
\hline & & Meski semua orang singkirkan kita & $\sqrt{ }$ & & \\
\hline & & Genggam tangan erat-erat kita melangkah & $\sqrt{ }$ & & \\
\hline \multirow{12}{*}{9} & \multirow{12}{*}{$\begin{array}{c}\text { Maaf Cintaku } \\
\text { Maaf } \\
\text { (Cinta) }\end{array}$} & Ingin kuludahi mukamu yang cantik & $\sqrt{ }$ & & \\
\hline & & $\begin{array}{l}\text { Agar kau mengerti bahwa kau memang } \\
\text { cantik }\end{array}$ & $\sqrt{ }$ & & \\
\hline & & Ingin kucongkel keluar indah matamu & $\sqrt{ }$ & & \\
\hline & & Agar engkau tahu memang indah matamu & $\sqrt{ }$ & & \\
\hline & & Harus kuakui bahwa aku pengecut & & & \\
\hline & & Untuk mencium mu juga merabamu & $\sqrt{ }$ & & \\
\hline & & Namun aku tak takut untuk ucapkan & $\sqrt{ }$ & & \\
\hline & & Segudang kata cinta padamu & & $\sqrt{ }$ & \\
\hline & & Mengertilah perempuan ku & & & \\
\hline & & Jalan masih teramat jauh & $\sqrt{ }$ & & \\
\hline & & $\begin{array}{l}\text { Mustahil berlabu bila dayung tak } \\
\text { terkayuh }\end{array}$ & $\sqrt{ }$ & & \\
\hline & & Maaf cintaku aku menggurui kamu & & $\sqrt{ }$ & \\
\hline \multirow{31}{*}{10} & \multirow{21}{*}{$\begin{array}{c}\text { O...Ea...Eo } \\
\text { Orang Pinggiran } \\
\text { (Kritik Sosial }\end{array}$} & Orang pinggiran o..ea..eo.. & & $\sqrt{ }$ & \\
\hline & & Ada di trotoar o...ea..eo.. & $\sqrt{ }$ & & \\
\hline & & Ada di bis kota o..ea..eo.. & $\sqrt{ }$ & & \\
\hline & & Ada di pabrik-pabrik o...ea....eo & $\sqrt{ }$ & & \\
\hline & & Orang pinggiran o..ea..eo & & $\sqrt{ }$ & \\
\hline & & Diterik mentari o..ea...eo & $\sqrt{ }$ & & \\
\hline & & Di jalan becek o...ea..eo & $\sqrt{ }$ & & \\
\hline & & Menyanyi dan menari o..ea..eo.. & $\sqrt{ }$ & & \\
\hline & & Lagunya nyanyian hati tarinya tarian jiwa & $\sqrt{ }$ & & \\
\hline & & Seperti tangis bayi di malam hari & $\sqrt{ }$ & & \\
\hline & & Sepinya waktu kala sendiri & $\sqrt{ }$ & & \\
\hline & & Sambil berbaring meraih mimpi & & $\sqrt{ }$ & \\
\hline & & $\begin{array}{l}\text { Menatap langit-langit tak peduli sebab } \\
\text { esok pagi kembali }\end{array}$ & & $\sqrt{ }$ & \\
\hline & & Orang pinggiran o..ea..eo & & $\sqrt{ }$ & \\
\hline & & Di dalam lingkaran o..ea..eo.. & $\sqrt{ }$ & & \\
\hline & & Berputar-putar o..ea..eo.. & $\sqrt{ }$ & & \\
\hline & & Kembali kepinggiran o..ea..eo.. & $\sqrt{ }$ & & \\
\hline & & Orang pinggiran bukan pemalas & $\sqrt{ }$ & $\sqrt{ }$ & \\
\hline & & Orang pinggiran pekerja keras & $\sqrt{ }$ & $\sqrt{ }$ & \\
\hline & & Orang pinggiran tidak mengeluh & $\sqrt{ }$ & $\sqrt{ }$ & \\
\hline & & Orang pinggiran terus melangkah & $\sqrt{ }$ & $\sqrt{ }$ & \\
\hline & & Berjalan seorang pria muda & $\sqrt{ }$ & & \\
\hline & & Dengan jaket lusuh dipundaknya & $\sqrt{ }$ & & \\
\hline & & Disela bibir tampak mengering & $\sqrt{ }$ & & \\
\hline & & Terselip sebatang rumput liar & $\sqrt{ }$ & & \\
\hline & & Jelas menatap awan berarak & & $\sqrt{ }$ & \\
\hline & & Wajah murung semakin terlihat & $\sqrt{ }$ & & \\
\hline & & Dengan langkah gontai tak terarah & $\sqrt{ }$ & & \\
\hline & & Kringat bercampur debu jalanan & $\sqrt{ }$ & & \\
\hline & & Engkau sajana muda resah mencari kerja & $\sqrt{ }$ & & \\
\hline & & Mengandalkan ijasahmu & $\sqrt{ }$ & & \\
\hline
\end{tabular}




\begin{tabular}{|c|c|c|c|c|c|}
\hline \multirow{16}{*}{11} & \multirow{16}{*}{$\begin{array}{l}\text { Sarjana Muda } \\
\text { (Kritik Sosial) }\end{array}$} & $\begin{array}{l}\text { Empat tahun lamanya bergelut dengan } \\
\text { buku }\end{array}$ & & $\sqrt{ }$ & \\
\hline & & Tuk jaminan masa depan & $\sqrt{ }$ & & \\
\hline & & Langkah kakimu terhenti & $\sqrt{ }$ & & \\
\hline & & Di depan halaman sebuah jawatan & $\sqrt{ }$ & & \\
\hline & & Tercengung lesu engkau melangkah & $\sqrt{ }$ & & \\
\hline & & Dari kantor yang kau harapkan & $\sqrt{ }$ & & \\
\hline & & Teriak kata tiada lowongan & $\sqrt{ }$ & & \\
\hline & & Untuk kerja yang didambakan & $\sqrt{ }$ & & \\
\hline & & Tak peduli berusaha lagi & $\sqrt{ }$ & & \\
\hline & & Namun kata sama kau dapatkan & $\sqrt{ }$ & & \\
\hline & & Jelas menatap awan ber arak & & $\sqrt{ }$ & \\
\hline & & Wajah murung semakin terlihat & $\sqrt{ }$ & & \\
\hline & & $\begin{array}{l}\text { Engkau sarjana muda resah tak dapat } \\
\text { kerja }\end{array}$ & $\sqrt{ }$ & & \\
\hline & & $\begin{array}{l}\text { Tak berguna ijasahmu empat tahun } \\
\text { lamanya }\end{array}$ & $\sqrt{ }$ & & \\
\hline & & Bergelut dengan buku sia-sia semuanya & & $\sqrt{ }$ & \\
\hline & & Setengah putus asa ia berucap maaf ibu & $\sqrt{ }$ & & \\
\hline \multirow{15}{*}{12} & \multirow{15}{*}{$\begin{array}{c}\text { Bento } \\
\text { (Kritik Sosial) }\end{array}$} & Namaku bento rumah real estate & $\sqrt{ }$ & & \\
\hline & & Mobilku banyak harta melimpah & $\sqrt{ }$ & & \\
\hline & & Orang memanggilku bos eksekutif & $\sqrt{ }$ & & \\
\hline & & Tokoh papan atas atas segalanya Asik...! & $\sqrt{ }$ & & \\
\hline & & Wajahku ganteng banyak simpanan & $\sqrt{ }$ & & \\
\hline & & Sekali lirik oke sajalah & $\sqrt{ }$ & & \\
\hline & & Bisnisku menjagal jagal apa saja & & & \\
\hline & & Yang penting aku senang aku menang & $\sqrt{ }$ & & \\
\hline & & Persetan orang susah karena aku & & & \\
\hline & & Yang penting asik sekali lagi asik..! & $\sqrt{ }$ & & \\
\hline & & $\begin{array}{l}\text { Khotbah soal moral omong keadilan } \\
\text { sarapan pagiku }\end{array}$ & & $\sqrt{ }$ & \\
\hline & & $\begin{array}{l}\text { Aksi tipu-tipu lobbying dan upeti } \\
\text { wow..jagonya }\end{array}$ & $\sqrt{ }$ & & \\
\hline & & $\begin{array}{l}\text { Maling kelas teri bandit kelas coro Itu } \\
\text { kantong sampah }\end{array}$ & & & \\
\hline & & Siapa yang mau berguru datang padaku & $\sqrt{ }$ & & \\
\hline & & $\begin{array}{l}\text { Sebut tiga kali nama } \\
\text { Bento..bento..bento.. Asik...!! }\end{array}$ & $\sqrt{ }$ & & \\
\hline \multirow{14}{*}{13} & \multirow{14}{*}{$\begin{array}{l}\text { Jendela Kelas Satu } \\
\text { (Cinta) }\end{array}$} & Duduk dipojok bangku deretan belakang & $\sqrt{ }$ & & \\
\hline & & Dalam kelas penuh dengan obrolan & $\sqrt{ }$ & & \\
\hline & & Selalu mengacu laju khayalan & & $\sqrt{ }$ & \\
\hline & & Dari jendela kelas yang tak ada kacanya & $\sqrt{ }$ & & \\
\hline & & Dari sana pula aku mulai & $\sqrt{ }$ & & \\
\hline & & Mengenal seraut wajah berisi lamunan & & $\sqrt{ }$ & \\
\hline & & Bibir merekah dan merah selalu basah & & $\sqrt{ }$ & \\
\hline & & Langkah mu tenang kala engkau berjalan & $\sqrt{ }$ & & \\
\hline & & Tinggi semampai gadis idaman & & $\sqrt{ }$ & \\
\hline & & Kau datang membawa sebuah cerita & $\sqrt{ }$ & & \\
\hline & & Darimu itu pasti lagu ini tercipta & $\sqrt{ }$ & & \\
\hline & & Dari jendela kelas yang tak ada kacanya & $\sqrt{ }$ & & \\
\hline & & Tembus pandang kekantin & $\sqrt{ }$ & & \\
\hline & & $\begin{array}{l}\text { Bertalu rindu datang mengetuk pintu } \\
\text { hatiku }\end{array}$ & & $\sqrt{ }$ & \\
\hline \multirow{12}{*}{14} & \multirow{12}{*}{$\begin{array}{l}\text { Aku bukan pilihan } \\
\text { (Cinta) }\end{array}$} & $\begin{array}{l}\text { Kini kau mengungkap Tanya siapakah } \\
\text { dirinya }\end{array}$ & $\sqrt{ }$ & & \\
\hline & & Yang mengaku kekasihmu itu & $\sqrt{ }$ & & \\
\hline & & $\begin{array}{l}\text { Aku tak bisa memahami ketika malam } \\
\text { tiba }\end{array}$ & $\sqrt{ }$ & & \\
\hline & & $\begin{array}{l}\text { Kurela kau berada dengan siapa kau } \\
\text { melewatinya }\end{array}$ & $\sqrt{ }$ & & \\
\hline & & Aku tak bias memahami & $\sqrt{ }$ & & \\
\hline & & $\begin{array}{l}\text { Aku lelaki tak mungkin menerima mu } \\
\text { bila }\end{array}$ & & & \\
\hline & & Ternyata kau mendua membuatku terluka & & & \\
\hline & & $\begin{array}{l}\text { Tinggalkan saja diriku yang tak sanggup } \\
\text { menunggu }\end{array}$ & $\sqrt{ }$ & & \\
\hline & & Jangan pernah memilih aku bukan pilihan & $\sqrt{ }$ & & \\
\hline & & Selalu terungkap Tanya benarkah kini dia & $\sqrt{ }$ & & \\
\hline & & $\begin{array}{l}\text { Wanita yang kukenalhatnya aku tak bisa } \\
\text { memahami }\end{array}$ & & $\sqrt{ }$ & \\
\hline & & $\begin{array}{l}\text { Tak perlu kau memilihku aku lelaki } \\
\text { bukan tuk dipilih }\end{array}$ & & & \\
\hline
\end{tabular}




\begin{tabular}{|c|c|c|c|c|c|}
\hline & & $\begin{array}{l}\text { Aku lelaki tak mungkin menerima mu } \\
\text { bila }\end{array}$ & & & \\
\hline & & Ternyata kau mendua membuatku terluka & & & \\
\hline & & $\begin{array}{l}\text { Tinggalkan saja diriku yang tak mungkin } \\
\text { menunggu }\end{array}$ & $\sqrt{ }$ & & \\
\hline & & Jangan pernah memilih aku bukan pilihan & $\sqrt{ }$ & & \\
\hline \multirow{27}{*}{15} & \multirow{27}{*}{$\begin{array}{l}\text { Bangunlah Putra } \\
\text { Putri Ibu Pertiwi } \\
\text { (Kritik Sosial) }\end{array}$} & Sinar matamu tajam namun ragu & & $\sqrt{ }$ & \\
\hline & & Kokoh sayapmu semua tau & $\sqrt{ }$ & & \\
\hline & & Tegap tubuh mu takan tergoyahkan & $\sqrt{ }$ & & \\
\hline & & Kuat jari mu kala mencengkram & $\sqrt{ }$ & & \\
\hline & & Brmacam suku yang berbeda & $\sqrt{ }$ & & \\
\hline & & Bersatu dalam cengkram mu & & $\sqrt{ }$ & \\
\hline & & Angin genit mengelus merah putih ku & & $\sqrt{ }$ & \\
\hline & & Yang berkibar sedikit malu-malu & & $\sqrt{ }$ & \\
\hline & & Merah membara tertanam wibawa & & $\sqrt{ }$ & \\
\hline & & Putih mu suci penuh karisma & & $\sqrt{ }$ & \\
\hline & & Pulau-pulau yang berpencar & $\sqrt{ }$ & & \\
\hline & & Bersatu dalam kibarmu & & $\sqrt{ }$ & \\
\hline & & Terbang lah garudaku & $\sqrt{ }$ & & \\
\hline & & singkirkkan kutu-kutu disayapmu & $\sqrt{ }$ & & \\
\hline & & Berkibarlah benderaku & $\sqrt{ }$ & & \\
\hline & & Singkirkan benalu ditiang mu & & & \\
\hline & & He..jangan ragu dan jangan malu & & $\sqrt{ }$ & \\
\hline & & $\begin{array}{l}\text { Tunjukan pada dunia bahwa sebenarnya } \\
\text { kita mampu }\end{array}$ & $\sqrt{ }$ & & \\
\hline & & Mentari pagi sudah memumbung tinggi & $\sqrt{ }$ & & \\
\hline & & Bangunlah putra putri ibu pertiwi & $\sqrt{ }$ & & \\
\hline & & $\begin{array}{l}\text { Mari mandi dan gosok gigi setelah itu } \\
\text { kita berjanji }\end{array}$ & $\sqrt{ }$ & & \\
\hline & & Tadi pagi esok hari atau lusa nanti & $\sqrt{ }$ & & \\
\hline & & Garuda bukan burung perkutut & $\sqrt{ }$ & & \\
\hline & & Sangsaka bukan sandang pembalut & & $\sqrt{ }$ & \\
\hline & & $\begin{array}{l}\text { Dan coba kau dengarkan pancasila itu } \\
\text { bukan lah rumus kode buntut }\end{array}$ & $\sqrt{ }$ & & \\
\hline & & Yang hanya berisikan harapan & $\sqrt{ }$ & & \\
\hline & & Yang hanya berisikan khayalan & $\sqrt{ }$ & & \\
\hline & & Jumlah & 176 & 54 & 29 \\
\hline
\end{tabular}

Berdasarkan deskripsi penelitian di atas yang diuraikan dengan berupa tabel, temuan penelitian tentang analisis makna konotatif dan denotatif baik positif dan negatif yang dikelompokan menjadi dua tema yaitu tema kritik sosial dan tema percintaan.

Misalnya pada satu judul lagu dengan tema cinta "Lalu kubisikan sebaris kata-kata putus asa sebentar lagi hujan". Bait lirik tersebut pada bait kesembilan, adalah bermakna denotasi atau makna yang sebenarnya. Lalu pada lirik "Membelah malam". Pada lirik ini kata "Membelah" adalah suatu yang dianggap memisahkan sesuatu kesatuan menjadi bagian-bagian, kata "Membelah' memiliki nilai rasa yang positif dibanding dengan 'Memotong', dalam lagu 22 Januari. Walau pun dalam lirik "membelah malam". bermakna idiom, yang maknanya masih dapat ditelusur atau dilacak dari makna unsur-unsurnya karena adanya 'asosiasi' antara makna asli dengan maknanya sebagai pribahasa. Lalu pada lirik "Aku berteman iblis yang baik hati". Pada lirik ini berkonotasi negatif, kata Aku berteman iblis lebih memiliki rasa negatif, kata "Berteman iblis" adalah suatu keburukan yang mengacu kepada kejahatan. Jadi lirik Aku Berteman Iblis Yang Baik Hati lebih memiliki nilai rasa negatif, dalam lagu 22 Januari. Walau pun dalam lirik "Aku berteman iblis yang baik hati" bermakna kias yaitu antara bentuk ujaran dengan makna yang diacu ada hubungan kias perbandingan atau persamaan.

Pada tema kritik sosial pun dapat kita lihat misalnya "Pernah kita sama-sama susah". Bait lirik tersebut terdapat pada lirik lagu karya Iwan Fals yang berjudul Belum Ada Judul pada bait pertama, adalah bermakna denotasi atau makna yang sebenarnya. "Terperangkap didingin malam". Pada lirik ini berkonotasi positif, kata 'Terperangkap' lebih memiliki rasa dari pada kata 'Terjerumus', dalam masyarakat pada umumnnya kata terperangkap memiliki nilai rasa yang baik, dalam lagu Belum Ada Judul. Walau pun dalam lirik "Terperangkap didingin malam" bermakna kias yaitu antara bentuk ujaran dengan makna yang diacu ada hubungan kias perbandingan atau persamaan. "Terjerumus dalam lubang jalanan". Pada lirik ini berkonotasi negatif, kata 'Terjerumus' lebih memiliki rasa negatif dari pada kata 'Terjebak', dalam masyarakat pada umumnnya kata terjerumus memiliki nilai rasa yang buruk, dalam lagu Belum Ada Judul. Walau pun dalam lirik "Terjerumus dalam lubang jalanan” 
bermakna kias yaitu antara bentuk ujaran dengan makna yang diacu ada hubungan kias perbandingan atau persamaan

Berdasarkan penafsiran dan uraian di atas, diketahui Peresentase keseluruhan penggunaan makna

1. denotatif sebesar $68.75 \%$, dari tema cinta dan kritik sosial yang diperoleh dari perhitungan sebagai berikut :

$$
\sum=\frac{x}{n} \mathrm{X} 100 \%
$$

Keterangan:

$$
\begin{aligned}
\sum & =\text { Data yang dicari } \\
\mathrm{x} & =\text { Jawaban dari data } \\
\mathrm{n}=\text { Jumlah sample } & \\
100 \% & =\text { Bilangan tetap } \\
\sum & =\frac{176}{256} \times 100 \% \\
= & 68.75 \%
\end{aligned}
$$

2. konotatif positif sebesar $21,09 \%$, dari tema cinta dan kritik sosial

3. konotatif negatif sebesar $11,32 \%$, dari tema cinta dan kritik sosial

\section{Simpulan}

Dari hasil penelitian tentang makan denotatif dan konotatif pada lirik lagu karya Iwan Fals yang diperoleh dari populasi keseluruhan sebanyak 150 judul lagu dari tahun 1981 sampai 2005, dengan sampel sebanyak 15 judul lagu yang dibagi menjadi 2 kategori, yaitu cinta sebanyak 8 judul lagu dan kritik sosial sebanyak 7 judul lagu, maka dapat diambil simpulan sebagai berikut:

\begin{tabular}{|c|l|c|c|c|}
\hline \multirow{2}{*}{ No } & \multicolumn{1}{|c|}{ Tema } & Denotasi & \multicolumn{2}{|c|}{ Konotasi } \\
\cline { 3 - 5 } & & & Negatif & Positif \\
\hline 1 & Cinta & 83 & 19 & 16 \\
\hline 2 & Kritik Sosial & 93 & 35 & 12 \\
\hline & & 176 & 54 & 28 \\
\hline
\end{tabular}

Bedasarkan penafsiran dan uraian diatas, diketahui penggunaan makna denotatif sebesar $68.75 \%$, penggunaan makna konotatif positif sebesar $21,09 \%$, penggunaan makna konotatif negatif sebesar $11,32 \%$, pada lirik lagu karya Iwan Fals yang bertemakan percintaan dan kritik sosial, tak bisa dipungkiri bahwa kehadiran makna denotatif akan selalu beriringan dengan makna konotatif. baik negatif maupun positif yang dipengaruhi oleh sebuah nilai rasa dari masyarakat.

\section{Ucapan Terima Kasih}

Terima kasih kepada tim editorial Jurnal Hortatori atas terbitnya artikel hasil penelitian ini. Terima kasih juga penulis ucapkan kepada semua pihak yang membantu proses penulisan artikel ini. 


\section{Daftar Rujukan}

Adha, Teti Laila. "Analisis Stilistika Lirik Lagu-Lagu Padi." Jurnal Pendidikan Dan Pembelajaran Khatulistiwa, vol. 1, no. 1, May 2017, pp. 10-11, https://jurnal.untan.ac.id/index.php/jpdpb/article/view/20204.

Afrinda, Putri Dian. "SARKASME Dalam LIRIK LAGU DANGDUT KEKINIAN (KAJIAN SEMANTIK)." Gramatika STKIP PGRI Sumatera Barat, 2016, doi:10.22202/jg.2016.v2i2.1040.

Agustina, Nova Dwi. ANALISIS PENGGUNAAN MAKNA DENOTATIF DAN KONOTATIF PADA PENULISAN BERITA SISWA KELAS VII DI SMP NEGERI 1 NGRAMPAL SRAGEN. no. August, 2016.

Halimah, Lely. "Musik Dalam Pembelajaran." EduHumaniora / Jurnal Pendidikan Dasar Kampus Cibiru, 2016, doi:10.17509/eh.v2i2.2763.

Jatmika, Ovan Bagus. "Faktor Penunjang Pertunjukan Musik : Input, Proses , Dan Output.” Journal of Music Science, Technology, and Industry, 2020.

Pradopo, Rahmat Djoko. Pengkajian Puisi. Gajah Mada University Press, 1990.

Sabriah. "Makna Denotatif Dan Konotatif Dalam Gelong Pare Toraja." Sariwegading, 2011.

Setiadi, Dwi. "CAMPUR KODE DALAM LIRIK LAGU 'KIS BAND.'” RETORIKA: Jurnal IImu Bahasa, 2017, doi:10.22225/jr.3.1.92.1-15.

Wahyuningsih, Tri Mulyani. "MAKNA DENOTATIF DAN KONOTATIF HANA (HIDUNG) PADA CERPEN 'HANA' KARYA AKUTAGAWA RYUNOSUKE." ALAYASASTRA, 2020, doi:10.36567/aly.v16i1.468. 